\title{
The Rhetoric of Agitation and Control's Roots in Movement Studies
}

\author{
David P. Schulz \\ Communications Department, Trinity Lutheran College \\ Everett, WA USA
}

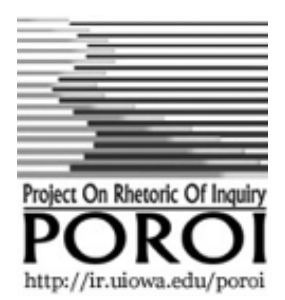

Poroi 9, 2 (August 2013)

Introducing the root trope in my title requires recognizing those responsible for giving rise to and nourishing the metaphorical root in rhetorical studies. We are a better discipline for the service and scholarship of John Waite Bowers, Donovan J. Ochs, Bruce Gronbeck, Jacqueline Schmidt, Richard Jensen, and many, many others. Many of us would not be in the discipline were it not for the continued graciousness of cultivators such as these who have, and continue, to welcome new scholars into the discipline.

I will start with a couple of confessions. First, I was thrilled at Gronbeck's invitation to contribute to this group of scholars. I confess I was also anxious as to how I might join a conversation that was initiated and well underway before I was born. I believe I was invited because of my contributions to the third edition of the Rhetoric of Agitation and Control [RAC] published in 2010. My entry took the form of new case studies that adopters of the book had requested. The core theoretical work of the book remains unadulterated. If the third edition is not as theoretically or conceptually updated as some would like, I confess that Bowers and Ochs' original theoretical observations have not been altered. I hope that commentary to follow will provide useful suggestions for the fourth edition.

Assuming many roles at a small liberal arts college does not provide much time to spend in the garden, but I have found brief moments in the summer months battling both rooted and rhizomatic vegetation. Those of us in rhetorical studies are practiced at transplanting tropes from different fields and this analysis joins that trend. I want to frame my observations using three botanical metaphors-roots, rhizomes, and mycrorhizza-that structure my thoughts on an evolving conversation surrounding the rhetoric of social movements generally and the $R A C$ in particular. I explore each species starting with the $R A C$ as a root, and conclude with some reflections on the future of the budding collaboration upon which Bowers reflected in his essay.

You do not have to be a master gardener to know that roots are the vertical conduits that bring life to a growing plant or tree. The root trope is often used to speak to disciplinary traditions. The root metaphor invokes imageries of vertically arranged feelers that serve as an evolving foundation and provide sustenance for a growing host. This metaphor of roots for conceptualizing protest rhetoric's evolution is an apt metaphor. 
While roots lie underground, they nevertheless endure, informing subsequent shoots, in this case the evolving project of rhetorical theory, criticism, and practice.

Yet there are other species that cohabit a garden, among them the rhizome whose offshoots often run horizontally versus vertically and are invoked to problematize vertical or rooted conceptualizations. ${ }^{1}$ The rhizome is the part of the plant that travels in the opposite direction of their vertically rooted counterparts. When a rhizome is separated into pieces, new iterations of the original plant continue to live. The metaphor of rhizome reflects the movements of both contemporary protest practices and theories. Taken together, roots and rhizomes introduce the concept of mutualism in theory, criticism, and practice. Mutualism refers to practices surrounding protest that inform each other in a symbiotic manner. This trope is apt because it reflects multiple entry and exit points in the representation and interpretation of knowledge, in this case the knowledge of persuasive collective action. As the distinction between roots and rhizomes establishes a binary I will explore a third concept, the mycorrhiza, a symbiotic/mutualistic relationship between vertical and horizontal flora that I will return to in my third and final observation as a botanical bridge between the roots of the past and the twists and turns of subsequent research. First, then, the roots.

\section{The Rhetoric of Agitation and Control's Roots}

The strength of a tree lies in its roots and one of the many fruitful and resilient roots our discipline produced was the pioneering work that Ochs and Bowers first planted in 1971. It is a special scholarly work that stimulates both theoretical and pedagogical responses. Let me suggest one such effect.

When I first read Bowers and Och's coauthored text, I was an undergraduate. I read the book for a special topics class on social movements taught through the political science department. I was a junior transfer student and that class and book were my first introduction to protest rhetoric. At the time of my reading, I was a political science major thinking this path would best prepare me for law school. However something happened on the way to that place. I was fascinated by the $R A C$ and immediately made many uses, including my first undergraduate research paper about Native American protest rhetoric, evidence for intercollegiate debates, and a guidebook (even though Bowers and Ochs advise against this in the first edition) for my own political activism.

Another confession: I was raised in a very politically conservative house and the book and the class were transformational to me both personally and politically. I became a "true believer" in rhetoric's capacity to make things happen. The $R A C$ provided me with (what were to be many) blueprints for exercising rhetorical agency, the capacity to set

\footnotetext{
${ }^{1}$ The rhizome metaphor entered the scholarly conversation with Deleuze and Guarttari (1980) in their efforts to advance a philosophy of multiplicities as opposed to arborescent horizontal modes of knowing and being. Numerous other scholars have taken up the rhizome metaphor including Castells (2012) as well as White and Sproule (2002).
} 
collective action rhetorically. To the dismay of my father, I did enact this agency through protests of hydroelectric dams and nuclear repositories slated for indigenous people's lands (at Yucca Mountain). The hits (and misses) continued from there.

The book inspired me to not only switch majors, but also enticed me off my law school path. Instead, I applied to graduate programs in communication studies to continue my exploration of social movements. Those of us who have read the book for a class can probably identify peers who have gone on to continue work in and around movements. One member of my cohort who read $R A C$ with me remained on the political science trajectory, going on to earn his doctorate in political communication. Another went to get a law degree and practice on behalf of dispossessed peoples. The list of those inspired to continue scholarly and practical work in protest events continues as Schmidt outlines in her essay.

I do not want to suggest that the book was an instrumental or a singular force. Yet a cursory search on Google Scholar reveals the dozens of theses, dissertations, journal articles and books at least have been informed by Bowers and Ochs' work.

Why has Bowers and Ochs' work had such a lasting impact in the face of critiques going back to its first edition? First, the $R A C$ represented a clear and concise entry point for understanding both rhetoric and its role in social change. Second, the book thoughtfully provided a method for comprehending the rationale of instrumental symbolic behavior through vibrant case studies from Chicago, San Francisco, and Birmingham that brought these contexts to life for those who did not live through these turbulent times. Third, the authors' writing style was accessible. These factors made the text a hardy species incredibly resilient to challenges over the past forty-one years.

Like many of my peers, I went on to study various approaches to "resistance" and "protest" rhetoric first at UNLV as an M.A. student under Richard Jensen and then at Pennsylvania State, where I studied protest rhetoric with Richard Gregg, J. Michael Hogan, and Stephen H. Browne. In each one of these classes I was introduced to a different theoretical challenge to the precepts laid out in my favorite green book. Among them was another green book, Kevin DeLuca's 1999 Image Politics, which usefully complicated the model laid out by Bowers and Ochs and other traditionalists. Rather than reduce these critiques to a particular school of thought or particular thinker, I prefer to characterize these complications as the rhizomatic challenge.

\section{Rhizome Challenges to The Rhetoric of Agitation and Control}

One of the defining characteristics of rhetorical theory and practices has been the capacity to evolve. As the ' 70 os passed into the ' 80 s and beyond, the model of social movements dialectically engaging establishment forces to drive reform and revolution began to be questioned both in theory and in practice. Models for redefining self-identities versus 
producing some thing (such as institutional reform) began to emerge under the moniker "New Social Movement" theory with Alberto Melucci (1989) and others at the forefront. Others emphasized identity politics reflected in public debates over race, class, and gender issues, and were producing re-conceptualizations of what was meant by the very concept of "social movements." Thus a host of new approaches to movements emerged across various disciplines, like the rhizome, spreading out horizontally and offering a counterpoint to established scholarship.

Gronbeck delves more thoroughly in tracing the evolution of social movement theory, so I will not spend too much time here other than to note that at every stop along my own circuitous path I encountered a variety of different perspective on protest rhetoric, running the gamut of what Medhurst (1993) has called generations of theoretical work in public address generally and protest scholarship in particular. From the pre-'6os to post-'6os, from the modern to the postmodern, the theoretical work both within and outside the rhetorical tradition that has transpired since 1971 has been dizzying, leading some to observe that the discipline still lacks a coherent approach to understanding social movements. Rather than focus on these theoretical twists and turns, I examine two other contextual changes that prompted the updated case studies for the third edition of $R A C$, and yet notice that the strategic skeleton of the book still offers an approach for understanding the rhetorical actions of agitators and establishments.

First, Internet Communication Technologies (ICTs) or New Communication Technologies (NCTs) have stimulated the roots and evolution of protest practices as well as the approaches for understanding these changes. At the dawn of the twenty-first century these technologies introduce new modalities not just for the transmission of protest messages but also for inventing, arranging, and most importantly collectively participating in such protest.

Some advantages protest movements have acquired through technological usage include a reduction of spatial and temporal constraints, decreased costs, and increased potential audience size. Agitators now can plan with a multitude of supporters around the world who can collectively participate in the design, development, and implementation of protest with much lower barriers (in terms of time, space, and costs) than earlier generations of protestors. And yet, for all of the hype, some of the major limitations associated with NCTs include dependency on technology to singlehandedly bring social change (technological determinism), the atomization of collectivities, information overload, and a digital divide. When intermixed, the advantages and disadvantages of NCTs in many ways facilitated a feature of contemporary protest: globalization. Following meetings of the WTO around the world simply would not have been possible before the introduction of NCTs.

A second closely related development in the recent evolution of collective protest practices is an increasing sense that anyone can engage and contribute meaningfully to a collective cause. While protestors of the '60s and '70s used mass media to communicate with larger publics, their appeals were often (re)framed through an intermediary media producer. 
Protestors' use of NCTs has allowed for more control over both the representation of appeals and the contribution of likeminded social actors around the world. This has led some theorists (e.g., Mertes, 2004) to propose a transglobal mega-movement or what has recently been called a "movement of movements" that challenges the traditional model of vertically organized protest groups which require established leaders, common physical space, reliance on mass media, etc. New avenues for advocacy have opened up inviting advocates around the world to join collectively in the creation and mobilization for mass demonstrations in opposition to multinational state and corporate actors but also to oppose less tangible ideologies such as capitalism, neoliberalism, heteronormativity, etc.

The rhetorical work of these new globalized movements reintroduces dialectical models of agitation and control that, when coupled with networked NCT technologies, augment the persuasive capacities of protest. Early evidence of the propensity for a global networked movement has surfaced in protests leading up to the global war on terror in Iraq and Afghanistan as well as the Occupy Movements and the Arab Spring of 2011.

And yet the more things change the more some things remain the same. Contemporary protests reveal how strategies from the ' 60 s and ' 70 s continue to influence current practices while also demonstrating new approaches to resistance. Present-day protests reveal how strategies from the ' 60 and ' 70 s continue to influence current practices while demonstrating new modalities. Particular strategies of protest that Bowers and Ochs first outlined in 1971 are still employed.

Protest strategies that continue to circulate contemporaneously include petition, promulgation, solidification, polarization, nonviolent resistance, escalation, and confrontation. These strategies are not exhaustive and do not include all rhetorical tools in the protest arsenal, but rather provide entry points for conceptualizing generic approaches that protestors used previously and that continue to inform contemporary protests. Moreover, these categories are not mutually exclusive and are not necessarily performed in the order presented here. Finally, each strategy remains reliant on rhetorical messaging. Much of that messaging remains similar to past practices both topically (e.g., antiwar, justice, equality) as well as in the particular forms of expression (speechmaking, chants, T-shirts, printed tracts). Following, strategies are reconsidered in light of both similarities to "6os iterations and similarities or differences in contemporary protest practices.

Petition was and remains a principal step disaffected people take to symbolically challenge the status quo. Petition ranges from written statements that identify problems as well as articulations of proposed solutions. This basic strategy continues to operate in the practices of protest and yet the rise of NCTs has altered both the form and function of the traditional petition. While physical paper continues to circulate on street corners across the United States with advocates urging citizens to sign a variety of formal appeals, the petition has taken on new life in the electronic age. For example, protest groups such as MoveOn.org have 
solicited sympathizers' digital signatures on numerous challenges to existing political reform. Activists for a cause can now lobby for signatures to any number of petitions online and allies can register support using cell phones in a fraction of the time that it took their predecessors to circulate paper petitions.

Historically, when a petition drive failed to secure desired change, dissenters would move to promulgation of messages in other ways. Promulgation can be understood as taking grievances and goals to wider publics with the aim of winning supporters. Traditional forms of promulgation included passing out leaflets that explained the problems within the status quo and putting up posters that articulated the protestor's position. Promulgation historically has employed the most recent technological developments to assist in the dissemination of messages. The use of NCTs these days has greatly enhanced this strategy. While dissenters continue to print hard copies of posters and leaflets, posting them around public areas, protestors can now digitize their messages and disseminate persuasive tracts to wider audiences in a costand time-efficient manner. The aim is to pressure establishment decision makers through the mass distribution of various messages, holding public meetings to inform and recruit the likeminded, targeting the media through staged events, and seeking legitimizers within the establishment who can advocate for the agitators' cause.

As protestors of the ' 60 s and ' 70 discovered, promulgation often raises public attention to a cause but does little to change established laws or practices, necessitating further action on the part of like-minded activists. Traditionally, solidification happened through physical meetings with the emergent group of agitators, as in Poland's Solidarity Movement. What has changed is that NCTs enable solidification to occur more quickly and efficiently, encouraging wider participation. For example, activists using social networking sites such as Facebook can supplement physical meetings with virtual meetings held in online spaces. The introduction of smart phones (cellular phones designed to optimize communication technologies such as the Internet) has made solidification practices even more decentralized and accessible to widespread audiences whose members have access to them. Most countries considered part of the Arab Spring have relied on smart phones when traditional Internet connections have been shut down.

Protestors, who remain aggrieved once solidification but nothing else has occurred, historically have shifted next to strategies of polarization. In polarization, a symbolic binary is advanced, creating clear divisions between the protestor and the establishment. That division is designed to draw sympathizers to a cause who have not yet committed to either side. Previously, the strategy frequently followed an identifiable pattern of choosing an establishment target and drawing sharp symbolic distinctions between establishment subjects and protestors. Creating polar oppositions also worked to affirm a person or platform from within the dissenting group with whom uncommitted audiences could identify and ultimately join. 
One can see remnants of ' 60 s polarization play out in many contemporary protest activities. Labor activists continue to use polarizing language strategies, such as calling those who cross a picket line during a labor strike "scabs." Posters and placards negatively framing establishment "flag individuals" and/or "flag issues" (an individual and/or issue who is synecdochically targeted as representing the establishment) continue to find contemporary expression on the streets of the twenty-first century as they did in the '6os.

However, the ability to polarize has been augmented with NCT developments. Polarization can occur using, for example, digital editing of imagery to create sharp contrasts between agitator and establishment. Following the U.S. invasion of Iraq in 2003, the Web was filled with imperialistic images of President George W. Bush. Once designed, these messages quickly can be disseminated to mass audiences in ways not possible during the ' 60 s. Flag individuals on both sides of a controversy can now communicate with constituencies effectively, reinforcing or refuting the claims the other side has made. Thus, many of the basic strategies of polarization remain sustained by root strategies from the past while simultaneously evolving to make use of contemporary technologies.

Resistance is another rhetorical mainstay in protest repertoires that assumes many different forms, with nonviolent resistance being the most visible. When protestors identified a policy that they could rally sufficient supporters to oppose, they traditionally confronted the establishment symbolically through sit-ins, boycotts, and strikes until the objectionable policy was addressed. For example, the '6os Student Movement saw collegians protesting university policies that restricted student speech by skipping classes, sitting in university buildings, and speaking out. Students would stage sit-ins of college administration buildings to visually confront the establishment while verbally attacking existing policies. Resistance strategies such as traditional sit-ins continue to inform contemporary protest but have mutated. For example, contemporary protestors have augmented the precepts of the sit-in using NCTs to invite flash mobs of activists to semi-spontaneous protests. Another example finds protestors who have inverted the traditional boycott, inviting sympathizers to use NCTs to visit an establishment actor's website at one time and overwhelm it. Such Denial of Service (DoS) attacks precipitate computer crashes, effectively disrupting an establishment's online presence for hours, days, or longer. Moveon.org used this electronic version of resistance when trying to stop the Iraq invasion in 2003.

Escalation represents another approach to protest. Escalation can be traced back to the 1840s, when the Catholic Association under Daniel O'Connell in Ireland used increasingly large "monster meetings" to threaten the British if concessions were not made to Irish selfgovernment. It continues to operate in contemporary protest. Escalation takes many symbolic forms including rumor, verbal and nonverbal challenges, and contrast. During the " 60 s dissenters employed strategies such as verbal rumor that forced establishment actors to prepare for potential physical confrontation. Dissenters would spread word of 
potential physical demonstrations in public places that forced establishment actors (such as city officials) to reallocate finite resources (police, security, etc.). Efforts to quell such alleged events often stretched institutional resources (i.e. requiring additional security) and could ultimately exhaust an establishment's ability to respond.

NCT's have greatly enhanced the ability to create and disseminate rumors and have forced establishment actors to create new digital security measures to counter escalation. Police in Seattle ran all over the city in pursuing rumors about places that protests were presumably occurring. A related tactic is what some have called the "silent slasher" wherein dissenters engage in the digital assassination of a government or corporate entity's credibility.

Confrontation often occurs when establishment and dissenters clash. Dissenters' symbolic challenges are designed to provoke an establishment's response. In cases where protestors fail to provoke confrontation, they may resort to token violent acts to further entice establishment reaction. Many '6os student occupations of university buildings did not initially provoke response from the established institutions, so many activists barricaded and physically blocked other symbols of the establishment such as police officers' cars. In one instance confrontation escalated when Mario Savio of the Berkeley Free Speech movement took off his shoes and climbed on top of a police car to deliver a speech to students at the University of California, Berkeley.

Such symbolic acts often prompted police to physical acts of confrontation with protestors. The clashes between police and protestor often became the subject of journalists' photographic and audio documentation, documents that brought the protestor's concerns to mass audiences. Equipped with NCTs, protestors no longer are reliant on journalists to convey their messages. Currently, protestors are their own media producers and can visually frame a confrontation with establishment actors and disseminate their outlook to widespread audiences using outlets such as YouTube. Such videos have been a hallmark of Arab Spring protests across northern Africa.

\section{Mycorrhiza: A Synthesis}

I began with what might have seemed a mixed metaphor of two seemingly incongruent species (rooted flora and rhizomes) to represent two strains in protest theories and practices. Perhaps going forward a better metaphor to describe developments in protest studies is the mycorrhiza. Mycorrhiza refers to symbiosis that occurs between the roots of a vascular species (such as a cedar tree) and a rhizome or fungal plant (ferns)-both of which reside in the Pacific Northwest. Symbiosis occurs as the rhizome works horizontally, colonizing existing roots and bringing minerals to the plant in exchange for nutrients.

This mutualistic relationship in nature offers a useful model for the theories and practices of public protest scholarship. While the roots of theoretical work such as the $R A C$ could not have anticipated the Internet or globalization, they nonetheless continue to offer an important basis from which new theorists and social actors draw insights. Theory is 
consequential and one of the consequences includes many of the scholars (and their scholarship) whom Schmidt referenced in her essay. Instead of theoretical posturing in which traditional theory is framed as passé while "new" theoretical advancements are viewed as supplanting the old, the mycorrhiza offers a useful synthesis model between the old and the new.

Undoubtedly, the theories and practices of social controversy and attendant public address will continue to spread both vertically from the past and horizontally in new directions. One example is the flood of recent work emanating from the work of Michael Warner (2002) on counterpublics and challenges to heteronormativity. New theories will, like the rhizome, often run counter to established traditions, helping us see new species of agitation such as everyday practices of living and being in the world. In this way rhetorical critics and theorists mirror the subjects they study. There are traditionalists who, through their research conserve an established understanding of social controversy, change, and public address. Such approaches bring a solid understanding of the roots of rhetoric in the rhetorical tradition. At the same time many scholars define themselves contra such approaches and seek alternative means to account for and thus theorize rhetoric's role in social controversy and change. I close by suggesting that these theoretical strands and species, unwittingly perhaps, collude with each other in a mutualistic relationship. For example, DeLuca's work on image politics invokes the $R A C$ even as it critiques that work.

Going forward there are a number of important lines of inquiry that are worth pursuing. First how can we continue to find interdisciplinary alliances? Bowers and Ochs did an exemplary job. Second, can we continue to expand our case studies beyond a prevailing focus on progressive causes and cases of the left? Third, as globalization continues to accelerate, how might we better engage international megamovements? Fourth, might new methodologies be needed to fully account for the unique approaches different cultures and emerging technologies bring to the practices of protest?

Whatever trajectories in the theory and criticism of public protest may emerge, one thing is certain: the work of Ochs and Bowers will continue to live on. Over the course of my relatively short career, students have found Bowers and Ochs work at once both accessible and applicable to the practices of their everyday lives. My hope in joining the collaboration was to beckon contemporary students into the conversation to which I was so warmly welcomed. Exploring new case studies may coax contemporary students to consider the past so that they might be invited to exercise their own rhetorical agency in both their critical practice and collectivities going forward.

In a recent call for continued rhetorical work, Zarefsky (2010, 81) notes "This is not just a matter of keeping our roots alive, important as that may be. It also gives depth and comparative perspective to our observations about the contemporary. It involves us in an important interdisciplinary conversation. And as students invariably discover, the past is not as different from the present as we sometimes assume." Scholars, students, and activists will continue to be informed by the 
taproot that Bowers and Ochs initially planted over forty-two years ago. I know that many of us remain indebted to Bowers and Ochs for introducing us to the rhetorics of agitation and control. As protest scholars, students, and activists continue to be informed by their work, it is my hope to honor this tradition by continuing the conversation and thereby informing the history of protest that is continuously unfolding and has yet to be written.

\section{References}

Castells, M. 2012. Networks of outrage and hope: Social movements in the internet age. Cambridge, UK: Polity Press.

Deleuze, G., and Guarttari, F. 1980/1984. A thousand plateaus. Trans. R. Hurley, M. Seem, and H.R. Lane. New York: Continuum.

DeLuca, K.M. 1999. Image politics: The new rhetoric of environmental activism. New York: Guilford Press.

Medhurst, M.J., ed. 1993. Landmark essays on American public address. Davis, CA: Hermagorus Press.

Melucci, A. 1989. Nomads of the present: Social movements and individual needs in contemporary society. Philadelphia, PA: Temple University Press.

Mertes, T., ed. 2004. A movement of movements: Is another world really possible? New York: Verso.

Warner, M. 2002. Publics \& counterpublics. New York: Zone Books.

White, R., and Sproule, W. 2002. Don't mourn the death of theory, organize! Continuum: Journal of Media \& Cultural Studies, 16:3, 317-33.

Zarefsky, D. 2010. Public address scholarship in the new century: Achievement and challenges. In S.J. Parry-Giles and Michael J. Hogan, eds., The handbook of public address (pp. 67-85). West Sussex, UK: Wiley-Blackwell. 